\title{
A VISÃO DO FEMININO NAS RELEITURAS BÍBLICAS DE SARAMAGO
}

Miguel Damian Ribeiro Pessoa é graduando em Letras na PUC-Rio.

E-mail: migueldrp@hotmail.com

\section{Resumo}

Este trabalho, realizado no âmbito do PETLetras da PUC-Rio, pretende comparar a formação e a construção de personagens femininas nas releituras bíblicas de Saramago - Caim (2009), referente ao Velho Testamento, e O evangelho segundo Jesus Cristo (1991), referente ao Novo Testamento - com o texto bíblico original, procurando estabelecer visões gerais da mulher em cada um deles e atentando para seus pontos de aproximação e afastamento. Saramago, conhecido por suas ideias polêmicas, traz em sua releitura uma visão atual da Bíblia, evidenciando preconceitos e concepções morais da época com reflexões irônicas e críticas comuns ao estilo do escritor. A análise terá uma abordagem mais focada em algumas das principais personagens dos romances - de Caim, em Eva e Lilith, e do Evangelho, em Maria, Maria Madalena e Jesus (incluído por trazer muitas reflexões sobre as mulheres). Personagens secundárias serão mais brandamente analisadas, sendo deixadas prioritariamente para comparações diretas com as personagens em evidência e/ou para tentativas de melhor entendimento da moral e das mentalidades gerais acerca do gênero feminino presentes em cada obra.

Palavras-chave: Saramago; gênero; Bíblia.

\begin{abstract}
This work, done as a contribution to PUC-Rio's PET-Letras, intend to compare the formation and construction of the female characters in Saramagos' Biblical retellings — Cain (2009), referred to the Old Testament, and The Gospel According to Jesus Christ (1991), referred to the New Testament - and those of the original Biblical text, trying to establish general visions of women in each one and highlighting their aspects of approximation and isolation. Saramago, known by his polemic ideas, puts in his retellings a current view of the Bible, showing prejudices and moral conceptions of the time with ironical reflections and critics common to the writer's style. The analysis will be focused on some of the main characters of the novels - in Cain, on Eve and Lilith, and in The Gospel, in Mary, Mary Magdelene and Jesus (included for his many reflections concerning women). Secondary characters will be more mildly analysed, being left primarily for direct comparisons with the characters in evidence and/or attempts of better comprehension of the general mentalities and morals concerning the female gender present in each novel.
\end{abstract}

Se algum dia uma personagem minha ficar na memória das pessoas, será a de uma dessas mulheres, e não porque eu predetermine sua maneira de ser ou atue mediante estratégias prévias. O caráter dessas mulheres nasce naturalmente, no meio da situação concreta que estou a narrar.

José Saramago

\section{1) INTRODUÇÃO}


A epígrafe deste trabalho, tirada da coletânea As palavras de Saramago (2010), ilustra perfeitamente uma visão geral das protagonistas femininas de José Saramago. Suas narrativas apresentam mulheres de forte caráter, que defendem ideias e valores próprios, rejeitando uma posição submissa aos homens. Ao voltar-se para o texto bíblico, tal discurso (que até os dias atuais mostra-se muitas vezes contra-hegemônico) assume proporções ainda maiores, já que a todo tempo critica a narrativa majoritariamente misógina presente nos Testamentos.

As questões das quais este artigo visa tratar então são: (i) de que forma a narrativa constrói estas críticas?; e (ii) como tal visão do sexo feminino é construída representacionalmente através das personagens?

Para fins introdutórios, à (i) poderia responder-se ligeiramente que o método apresentado nas obras em questão, comum a muitas narrativas do autor, apoia-se em dois pilares saramaguianos: nos comentários quase sempre irônicos do narrador, e nas próprias ações e pensamentos das personagens presentes nos textos.

À (ii), pode-se responder notando o papel agente - como oposto a um passivo, submisso - das personagens femininas de maior evidência (com apenas uma exceção real entre as analisadas). Voltando à epígrafe deste trabalho, é interessante perceber a visão do próprio autor acerca deste aspecto de suas personagens femininas; são elas dotadas de tão forte caráter que acabam por obscurecer até mesmo o próprio Saramago, fugindo ao controle de seu próprio "criador". Tal ideia é duplamente observável em Caim e n'O evangelho segundo Jesus Cristo, cujas narrativas possuem uma personificação do "criador" — Deus — que, assim como Saramago, também mostra-se ineficaz em assumir um papel superior ao das mulheres das obras. Este aspecto alinhase a um pensamento feminista beauvoiriano, no qual, seguindo seus conceitos antiessencialistas, a mulher é submissa ao homem por se aceitar submissa, escapando dessa posição ao tomar para si o poder de decidir e atuar ativamente em seu meio. Nas palavras da própria autora, "se a mulher se enxerga como o inessencial que nunca retorna ao essencial é porque não opera, ela própria, esse retorno" (BEAUVOIR, 1970, p. 13). As personagens das releituras analisadas aqui, pode-se afirmar, são majoritariamente mulheres que "operam esse retorno".

Neste artigo, aproveita-se a relação entre estudos culturais e literatura proposta por Jonathan Culler em seu livro Teoria Literária: uma introdução (1999), onde diz que "o projeto dos estudos culturais é compreender o funcionamento cultural" (CULLER, 1999, p. 49). Assim, através desta comparação entre a Bíblia e suas releituras saramaguianas, é feita uma tentativa de se tratar de assuntos não só concernentes à época dos escritos religiosos, mas também à visão contemporânea de tais escritos.

Saramago, muito atacado pelas comunidades cristãs e judaicas após os lançamentos destas obras, fez de suas releituras bíblicas uma oportunidade de evidenciar aspectos que considerava problemáticos no texto original. A misoginia, preconceito já trabalhado pelo autor em muitas outras obras, não poderia ficar de fora. Um dos primeiros cuidados da narrativa parece ser aprofundar as personagens femininas, colocando-as em cena em momentos nos quais a Bíblia parece oportunamente tê-las 
excluído. $\mathrm{O}$ que surge da maior abrangência deste foco narrativo é a força de suas personagens e grandes amostras das precárias relações entre diferentes gêneros comumente associadas às épocas em questão, pano de fundo para toda uma reflexão acerca da presença feminina não só no meio religioso, mas também no econômico e sócio-cultural.

\section{2) CAIM}

Caim foi o último livro do autor lançado em vida. Nela, o protagonista que dá título a obra passa por alguns dos mais conhecidos trechos do Velho Testamento, principalmente do Pentateuco. Saramago, com uma visão moderna acerca desta primeira parte bíblica, acentuou a brutalidade contida em suas histórias, inserindo seus já citados comentários críticos e irônicos.

Duas mulheres se destacam na obra: Eva, apresentada como a "primeira mulher" de acordo com a versão bíblica atual, e Lilith, suprimida das versões bíblicas rabínicas há séculos e aos poucos apagada também da consciência coletiva (SICUTERI, 1987, p. 3). Ambas são construídas por Saramago como mulheres fortes, que não hesitam em assumir a responsabilidade das situações nas quais se encontram, mesmo que não concernentes apenas a elas mesmas. Em Caim, características como essas são ainda mais importantes, dado que já no primeiro capítulo há a condenação divina da mulher à submissão ao homem. Eva e Lilith, para Saramago, são desde o princípio rebeldes a Deus, e como tal rebeldes à sociedade como um todo.

É interessante notar que as duas primeiras companheiras de Adão, tidas pelas narrativas religiosas como praticamente opostas, foram aproximadas por Saramago. Isso se deu com base em dois aspectos, um físico e um psicológico: físico, pela separação espaço-temporal criada pelo autor - se ambas surgissem, como na tradição, como companheiras de Adão, seriam colocadas desde o início em posição de rivalidade, dificultando ou até impossibilitando uma semelhança entre elas; e psicológico, interferindo principalmente no perfil tradicional de Eva, dotando-a de um maior entendimento e capacidade de agir sobre as situações em que é colocada. As duas também se aproximam por suas sexualidades e pelo uso que fazem destas, aspecto que, apesar de passível de questionamentos num espectro feminista, sem dúvida contribui para a alçada delas a uma posição de poder estranha às sociedades em que habitavam.

Adão, por sua vez, será deixado de lado neste estudo, pois apesar de ser entendido por alguns teólogos como um ser inicialmente andrógino (SICUTERI, 1987, pp. 5-10), Saramago não faz menção nem direta a esse aspecto, nem abre deixas para tal, visto que no início de Caim já estão presentes tanto Adão quanto Eva enquanto indivíduos separados. Sua presença neste artigo será pequena, apenas para fins comparativos e/ou explicativos.

\section{1) EVA}


Apesar das grandes alterações feitas no Velho Testamento, o autor não adentra a histórica querela acerca de quem foi a primeira mulher de Adão (Eva ou Lilith). Preferindo as versões bíblicas atuais, Saramago aproveita a posição já tradicionalmente consagrada de Eva e desloca Lilith para um cenário totalmente diverso. Entretanto, não deixa de fazer alterações significativas no caráter da "primeira mulher". Se Eva já poderia ser classificada como "rebelde a Deus" na tradição cristã apenas por ter sido a primeira a desrespeitar a lei divina e comer o fruto proibido, em Caim ela assume um papel ainda mais rebelde. Nos únicos três capítulos em que aparece na obra, a personagem se coloca em disputa com Deus com frequência, seja contestando Sua palavra, como no diálogo acerca do fruto proibido, onde já é possível perceber a desavença entre Ele e Eva (SARAMAGO, 2009, pp. 19); seja agindo diretamente contra os preceitos divinos, como quando relaciona-se com o Querubim. Comecemos analisando o primeiro caso.

[...] adão disse, A mulher que tu me deste para viver comigo é que me deu do fruto dessa árvore e eu comi. Revolveu-se o senhor contra a mulher e perguntou, Que fizeste tu, desgraçada, e ela respondeu, A serpente enganou-me e eu comi, Falsa, mentirosa, não há serpentes no paraíso, Senhor, eu não disse que haja serpentes no paraíso, mas digo sim que tive um sonho em que me apareceu uma serpente, e ela disse-me, Com que então o senhor proibiu-vos de comerem o fruto de todas as árvores do jardim, e eu respondi que não era verdade, que só não poderíamos comer do fruto da árvore que está no meio do paraíso e que morreríamos se tocássemos nele, As serpentes não falam, quando muito silvam, disse o senhor, A do meu sonho falou, E que mais disse ela, podese saber, perguntou o senhor, esforçando-se por imprimir às palavras um tom escarninho nada de acordo com a dignidade celestial da indumentária, A serpente disse que não teríamos que morrer, $\mathrm{Ah}$, sim, a ironia do senhor era cada vez mais evidente, pelos vistos, essa serpente julga saber mais do que eu, Foi o que eu sonhei, senhor, que não querias que comêssemos do fruto porque abriríamos os olhos e ficaríamos a conhecer o mal e o bem como tu o conheces, senhor, E que fizeste, mulher perdida, mulher leviana, quando despertaste de tão bonito sonho, Fui à árvore, comi do fruto e levei-o a adão, que comeu também, Ficou-me aqui, disse adão, tocando na garganta (SARAMAGO, 2009, pp. 16-17).

Nesse extenso trecho pode-se observar, além do ímpeto da personagem em discutir com Deus, diversas importantes características não só de Eva, mas também de suas relações com Deus e Adão. As falas de Adão que abrem e fecham o excerto já indicam dois de seus aspectos que, em contraste com os de Eva, invertem a relação de dominância entre homem e mulher comumente associada à tradição bíblica. Adão demonstra-se submisso, não inquisitivo, aceitando de bom grado quaisquer repreensões divinas que Eva ou rejeita completamente ou discorda em termos. A "covardia" atribuída ao Adão de Saramago apenas reflete e destaca a coragem de Eva, assim como a incapacidade dele de lidar com seus feitos faz sobressair a imensa capacidade dela.

Em Caim, Eva é superior em seu relacionamento com Adão, o que leva a outro exemplo de rebeldia ao comando divino: entre as punições impostas a ela por Deus (retiradas sem alterações semânticas do texto bíblico) encontra-se "e não obstante sentirás atracção pelo teu homem, e ele mandará em ti" (SARAMAGO, 2009, p. 18). Também contrastando com essa "elevação" da personagem de Eva, tem-se a sátira do 
narrador ao próprio personagem de Deus, que além de não ser onisciente - ele vai a Adão e Eva ainda sem respostas para suas perguntas — é "ironizado por suas falas irônicas", o que ainda pode ser visto como uma certa tentativa de equiparação entre o narrador e o próprio Deus. Rebaixando-O, Eva ganha ainda mais destaque no confronto, demonstrando poder até mesmo em uma relação com o divino.

Saltando para o episódio com o Querubim, outra importante característica de Eva pode ser percebida:

[...] Vantagem de ser anjo, disse eva, e sorriu. O querubim gostou de ver aquele sorriso. No céu também se sorria muito, mas sempre seraficamente e com uma ligeira expressão de contrariedade, como quem pede desculpa por estar contente, se àquilo se podia chamar contentamento. Eva tinha vencido a batalha dialéctica, agora só faltava a da comida. Disse o querubim, Vou trazer-te alguns frutos, mas tu não o digas a ninguém, A minha boca não se abrirá, em todo o caso o meu marido vai ter de saber, Volta com ele amanhã, temos que conversar. Eva retirou a pele de cima dos ombros e disse, Usa isto para trazeres a fruta. Estava nua da cintura para cima. A espada silvou com mais força como se tivesse recebido um súbito afluxo de energia, a mesma energia que levou o querubim a dar um passo em frente, a mesma que o fez erguer a mão esquerda e tocar no seio da mulher. Nada mais sucedeu, nada mais poderia suceder, os anjos, enquanto o sejam, estão proibidos de qualquer comércio carnal, só os anjos que caíram são livres de juntar-se a quem queiram e quem os queira. Eva sorriu, pôs a mão sobre a mão do querubim e premiu-a levemente contra o seio. (SARAMAGO, 2009, pp. 24-25).

Nesta passagem se nota a sexualidade de Eva, praticamente ignorada no texto bíblico original, se não relacionada à maternidade ou a alguma restrição divina. Mas é importante também notar que Eva ganhara "a batalha dialéctica" durante o diálogo anterior ao trecho destacado, diminuindo a carga utilitária de sua sexualidade que poderia ser atribuída à situação. Em Retratos para a construção da identidade feminina na prosa de José Saramago, dissertação de mestrado de Pedro Neto, lê-se: "Eva constitui, com isso, um afrontamento à palavra do macho e a exterioridade do mundo dos homens - é sua palavra-fêmea frente à do Criador-macho" (NETO, 2012, p. 94). E, tendo isso em mente, é importante lembrar o que isso significava na sociedade em questão. Como colocado por Zolin:

A mulher que tentasse usar seu intelecto, ao invés de explorar sua delicadeza, compreensão, submissão, afeição ao lar, inocência e ausência de ambição, estaria violando a ordem natural das coisas, bem como a tradição religiosa. [...] A condição de subjugada da mulher deve ser tomada como de origem divina (ZOLIN in BONNICI \& ZOLIN, 2004, p. 164).

Após alcançar a vitória intelectualmente sobre o Querubim (atente: representante divino), ela se permite flertar com o anjo, conseguindo seduzir até mesmo ele, um ser supostamente assexuado. Sua sexualidade, ao oferecer prazeres inexistentes no Paraíso - lugar onde se sorri "quase sempre seraficamente e com uma ligeira expressão de contrariedade" - é tamanha que induz à rebeldia até mesmo os mais leais servos de Deus. Eva conquista ao mesmo tempo uma vitória sobre o homem, ao despertar um desejo primariamente impossível, e sobre Deus, ao incitar uma revolta angélica. 
Se a Eva clássica já foi remodelada para os padrões saramaguianos de personagens femininas, analisemos em seguida um já tradicional exemplo de mulher que subverte as relações de dominância patriarcais, e como ela foi apresentada em Caim.

\section{2) LILITH}

O mito de Lilith aparece em diversas culturas, sempre com características semelhantes: principalmente como a primeira mulher, e como rebelde à submissão da mulher ao homem. Na cultura judaico-cristã, essa rebeldia a ela atribuída causou inclusive a sua supressão dos textos bíblicos, ao mesmo tempo em que transfigurou-a na personificação do demônio original, segundo algumas Escrituras rabínicas (SICUTERI, 1987, p. 11), fato que pode também ser explicado pelas palavras de Zolin citadas anteriormente.

Saramago, embora tenha aceito a supressão de Lilith como a primeira companheira de Adão em Caim, construiu em um cenário novo uma personagem semelhante à sua versão mítica, que não só mantém o seu papel dominante em seu meio como inclusive apresenta algumas características "demoníacas" para sua sociedade, significando aqui aspectos que vão contra a manifesta "vontade divina". Analisemos a aparição de Lilith em Caim:

E o senhor daqui, é quem, O senhor é senhora e o seu nome é lilith, Não tem marido, perguntou caim, Creio ter ouvido dizer que se chama noah, mas ela é quem governa o rebanho, $[. .$.$] e aí viram num balcão uma mulher vestida com tudo o que devia ser o$ luxo do tempo e essa mulher, que à distância já parecera belíssima, olhava-os como absorta, como se não desse por eles, Quem é, perguntou caim, É lilith, a dona do palácio e da cidade, oxalá não ponha olhos em ti, oxalá, Porquê, Contam-se coisas, Que coisas, Diz-se que é bruxa, capaz de endoidecer um homem com os seus feitiços, Que feitiços, perguntou caim, Não sei nem quero saber, não sou curioso, a mim basta-me ter visto por aí dois ou três homens que tiveram comércio carnal com ela, E quê, Uns infelizes que davam lástima, espectros, sombras do que haviam sido, Deves estar louco se imaginas um pisador de barro a dormir com a rainha da cidade, Queres dizer a dona, Rainha ou dona, tanto faz, Vê-se que não conhece as mulheres, são capazes de tudo, do melhor e do pior se lhes dá para isso, são muito senhoras de desprezar uma coroa em troca de irem lavar ao rio a túnica do amante ou atropelarem tudo e todos para chegar a sentar-se num trono (SARAMAGO, 2009, pp. 49-51).

Neste trecho já é possível observar a dominância de Lilith sobre os homens: seu marido, Noah, de tão imperceptível mal é conhecido pelos seus conterrâneos, e de forma alguma impede as relações dela com outros homens; dentre estes conterrâneos, a visão de Lilith é a de uma destruidora de homens, que os reduz até serem "sombras do que haviam sido", o que contribui para a sua posição de "dona da cidade" ao infligir medo nos homens que pudessem rebelar-se à dominância feminina; vê-se também que, a um simples "pisador de barro", resta ter esperanças do olhar de Lilith não o notar, já que a sua vontade o obrigaria a uma posição sexualmente servil. E, mesmo após todos estes fatores, ela ainda parece "absorta, como se não desse por eles", reafirmando sua superioridade através de um simples olhar que reduz os homens à insignificância. Ainda 
assim, a mentalidade masculina comum acerca das mulheres ainda traz traços de um sentimento de diferença que pode, também, ser interpretada como de "superioridade", ao declarar que as mulheres "são capazes de tudo". A mulher "dona", "rainha", é vista como um enigma para o homem comum, que vê nessa impossibilidade de definição uma fraqueza - fraqueza esta inexistente, em termos práticos.

Logo a seguir, tem-se o chamado de Lilith a Caim:

[...] mas essa foi exactamente a mesma que lilith, semanas mais tarde, virá a pronunciar, letra por letra, quando mandou chamar o homem de quem lhe haviam dito que se chamava abel, Entra. [...] A entrada no palácio foi, desta vez, pela porta principal porque aqui nada se faz às escondidas, se a dona lilith arranjou um novo amante, melhor é que se saiba já, que não se arme aqui todo um jogo de segredinhos e maledicências, toda uma rede de risotas e murmurações, como infalivelmente sucederia em outras culturas e civilizações (SARAMAGO, 2009, pp. 52-56).

De nada adiantara as súplicas do olheiro apresentadas no trecho anterior: uma palavra de Lilith é suficiente para obrigar qualquer homem de sua cidade à sua presença. Caim, adotando o nome de Abel, não é diferente. A "dona da cidade" também não se deixa enfraquecer por rumores e boatos - livra-se deles da forma mais direta possível, assumindo seus casos extraconjugais, sem ter nada a esconder. Neste excerto, o próprio narrador indica o contraste entre tal modus operandi da cidade de Lilith e "outras culturas e civilizações", servindo o comentário também de explicação ao porquê deste contraste. Lilith rejeita normas patriarcais peremptoriamente, minando as bases mais simples delas com atitudes diretas e francas, lembrando muito o pensamento feminista de Beauvoir. Aqui, sem dúvida, a narrativa começa a brandamente desconstruir a ideia de Lilith como um ser "demoníaco". Tal desconstrução, entretanto, só é concluída quando a relação de poder entre os gêneros também o é, quando Lilith deixa de ser (se portar como, demonstrar-se) superior a Caim e o vê como um igual. Isso se dá através não da relação sexual entre os dois, mas através da relação amorosa. Dois acontecimentos consolidam esse novo estágio das personagens: primeiro, a confissão de Caim, que estabelece a confiança necessária, e, posteriormente, a resposta de Lilith ao ataque orquestrado por Noah a Caim, que demonstra a vontade dela de criar entre eles uma relação de igualdade:

Então caim abriu a arca dos segredos e relatou o dramático sucesso com todos os pormenores, não esquecendo as moscas nos olhos e na boca de abel, também as palavras ditas pelo senhor, o enigmático compromisso por ele assumido de o proteger de uma morte violenta, Não me perguntes, disse caim, por que o fez, não mo disse e não creio que seja coisa que se possa explicar, A mim basta-me que estejas vivo e nos meus braços, disse lilith, Vês em mim um criminoso a quem nunca se poderá perdoar, perguntou caim, Não, respondeu ela, vejo em ti um homem a quem o senhor ofendeu, e, agora que já sei como realmente te chamas, vamos para a cama, arderei aqui mesmo de desejo se não me acodes, foste o abel que conheci entre os meus lençóis, agora és o caim que me falta conhecer (SARAMAGO, 2009, pp. 66-67).

Tive uma ideia, Qual, Matar noah, Isso é uma loucura, um disparate sem pés nem cabeça, protestou caim, expulsa esse absurdo do teu ânimo, por favor, Absurdo, porquê, ficaríamos livres dele, casaríamos, tu serias o novo senhor da cidade e eu a tua rainha e 
a tua escrava preferida, aquela que beijaria o chão por onde tu passasses, aquela que, se fosse necessário, receberia nas suas mãos as tuas fezes, E quem o mataria, Tu, Não, lilith, não mo peças, não mo ordenes, já tenho a minha parte de assassínios, Não o farias por mim, não me amas, perguntou ela, entreguei-te o meu corpo para que o gozasses sem conta, nem peso, nem medida, para que desfrutasses dele sem regras nem proibições, abri-te as portas do meu espírito antes trancadas, e recusas-te a fazer algo que te peço e que nos traria a liberdade plena, Liberdade, sim, e remorso também, Não sou mulher para remorsos, isso é coisa para fracos, para débeis, eu sou lilith (SARAMAGO, 2009, p. 69).

Assim que a relação entre os dois é ressignificada pela confissão de Caim e em seguida atacada por Noah, Lilith se vê em uma posição até então estranha a ela. Ainda sem perder o controle intelectual da situação, pede a Caim que mate Noah, não eximindo-se de inferiorizar-se em suas súplicas. Entretanto, essa inferioridade não se mantém por mais do que algumas falas. Vê-se que este papel de subjugada, exercido por Lilith quando diz que seria a "que beijaria o chão por onde [Caim] passass[e]", é apenas uma atuação momentânea para a eventual conquista de seus desejos, sendo logo deixado de lado quando ela percebe a recusa de Caim (Ela é Lilith, não uma "mulher para remorsos"). Ainda assim, a vontade expressa por ela de fazer Caim senhor da cidade $a o$ seu lado é real, assim como o amor que sente por ele. Tem-se aí a consolidação do novo relacionamento entre o casal, que agora se vê equiparado em termos de poder.

Vê-se então que a Lilith de Saramago, apesar de partilhar características com a Lilith da tradição judaico-cristã, contrasta em diversos pontos com esta versão. Tal remodelação da personagem pode tanto ser vista como uma adaptação da "essência demoníaca" de Lilith às normas patriarcais quanto como uma superação das relações de opressão entre gêneros, opção que depende mais da visão ou da simpatia do leitor para com o texto do que factualmente do seu conteúdo.

\section{3) O EVANGELHO SEGUNDO JESUS CRISTO}

O evangelho segundo Jesus Cristo (que a partir de agora será referido como ESJC), lançado em 1991, gerou uma repercussão muito maior que Caim. A grande comunidade cristã de Portugal não aceitou bem a obra, chegando a "obrigar" Saramago a se exilar na Espanha. A narrativa, que mostra os acontecimentos do Novo Testamento pelos olhos de Jesus, foi chamada de herética e desrespeitosa, o que, visto por uma perspectiva estritamente católica, dificilmente pareceria uma acusação infundada.

Cibele Lopresti Costa, em seu artigo "A ética em $O$ evangelho segundo Jesus Cristo, de José Saramago", aponta para uma "dessacralização" da personagem de Jesus (In: FERRAZ, 2008, pp.183-185), o que a princípio parece alinhar-se à reação do público português. Afirmarei, entretanto, o contrário: Jesus, na obra de Saramago, assim como as outras personagens divinas (Deus, o Diabo) não é dessacralizado, mas tem o seu papel religioso adaptado a uma problematização da moral completamente oposta ao texto bíblico original.

Essa mudança drástica no conceito de moral é correspondente a uma virada epistemológica do século XX sobre o tema, iniciada principalmente com as obras de 
Nietzsche A genealogia da moral (2009) e Para além do bem e do mal (2002). Ao longo de todo o livro é possível acompanhar este pensamento, observando as dúvidas de Jesus, o seu convívio com o Diabo, suas conversas com Deus, entre muitas outras situações. E, embora esse "detalhe" pareça pouco relacionado ao tema deste artigo, uma análise mais vigorosa do texto deixa transparecer a extrema importância deste traço ideológico da obra para o entendimento de suas personagens.

É também importante deixar desde já registrado que Saramago não excluiu a opressão sofrida pelas mulheres na época dos acontecimentos narrados. Muito pelo contrário: o autor parece destacar suas condições precárias, podendo assim abordar criticamente tais condições através de seus comentários e de suas personagens femininas de maior evidência.

Sigamos para elas.

\section{1) MARIA}

Maria, a mãe de Jesus, mostra-se na obra a personagem mais convencional dentre as analisadas - convencional num sentindo primário, de quem obedece às convenções de sua sociedade. Ainda que, como todas as personagens femininas presentes neste estudo, sua participação tenha sido aprofundada e detalhada, Maria não se opõe às normas de sua época. Antes de adentrar nos pensamentos que baseiam esta visão, vejamos um trecho muito significativo à construção da personagem:

Sem pronunciar palavra, José aproximou-se e afastou devagar o lençol que a cobria. Ela desviou os olhos, soergueu um pouco a parte inferior da túnica, mas só acabou de puxála para cima, à altura do ventre, quando ele já se vinha debruçando e procedia do mesmo modo com a sua própria túnica, e Maria, entretanto, abrira as pernas, ou as tinha aberto durante o sonho e desta maneira as deixara ficar, fosse por inusitada indolência matinal ou pressentimento de mulher casada que conhece os seus deveres. Deus, que está em toda a parte, estava ali, mas sendo aquilo que é, um puro espírito, não podia ver como a pele de um tocava a pele do outro, como a carne dele penetrou a carne dela, criadas uma e outra para isso mesmo, e, provavelmente, já nem lá se encontraria quando a semente sagrada de José se derramou no sagrado interior de Maria, sagrados ambos por serem a fonte e a taça da vida, em verdade há coisas que o próprio Deus não entende, embora as tivesse criado. Tendo pois saído para o pátio, Deus não pôde ouvir o som agónico, como um estertor, que saiu da boca do varão no instante da crise, e menos ainda o levíssimo gemido que a mulher não foi capaz de reprimir. Apenas um minuto, ou nem tanto, repousou José sobre o corpo de Maria. Enquanto ela puxava para baixo a túnica e se cobria com o lençol, tapando depois a cara com o antebraço, ele, de pé no meio da casa, de mãos levantadas, olhando o tecto, pronunciou sobre todos terrível bênção, aos homens reservada, Louvado sejas tu, Senhor, nosso Deus, rei do universo, por não me teres feito mulher. Ora, a estas alturas, Deus já nem no pátio devia estar, pois não tremeram as paredes da casa, não desabaram, nem a terra se abriu. Apenas, pela primeira vez, se ouviu Maria, e humildemente dizia, como de mulheres se espera que seja sempre a voz, Louvado sejas tu, Senhor, que me fizeste conforme a tua vontade, ora entre estas palavras e as outras, conhecidas e aclamadas, não há diferença nenhuma, repare-se, Eis a escrava do Senhor, faça-se em mim segundo a tua palavra, está patente que quem disse isto podia, afinal, ter dito aquilo. Depois, a mulher do carpinteiro José levantou-se da esteira, enrolou-a juntamente com a do marido e dobrou o lençol comum (SARAMAGO, 2011, pp. 18-19). 
Desse extenso excerto pode serem tiradas as principais características de Maria relevantes a este estudo. Primeiramente, pode-se observar a mudança diegética elaborada pelo autor acerca da sexualidade de Maria - não só Saramago apresenta uma cena de sexo entre José e Maria, como a constrói como um fato recorrente, comum, já inerente à vida do casal. Focando em Maria, é também importante notar que ela não oferece resistência à relação sexual e, considerando seu "levíssimo gemido", demonstra certa satisfação com o ato. Se a princípio tal alteração apresenta-se quase como uma previsível mostra de rebeldia da personagem quando comparada ao texto bíblico, a narrativa insiste em dizer o contrário: Maria segue o seu caráter de "mulher casada que conhece os seus deveres". Deus tampouco a reprova: apenas se retira do ambiente, pois "há coisas que [...] não entende, embora as tivesse criado".

As bênçãos descritas a seguir apenas reiteram o caráter misógino do trio Deussociedade-marido, bênçãos estas retiradas das próprias recomendações judaicas e problematizadas pelo narrador imediatamente $(\mathrm{SCHACH}, 2012$, p. 64). Maria, a convencional, é tal por aceitar sem questionamentos as normas deste "trio opressor". Se, na Bíblia, esse aspecto pudesse ser visto como o motivo da "divinização" da personagem, no ESJC o mesmo é a causa-mor de sua submissão e, consequentemente, de sua dissipação na obra. Embora Maria apareça mais na obra de Saramago, em termos simples de presença no texto, sua importância é consideravelmente menor do que no texto bíblico, principalmente por não partilhar dos impasses morais apresentados por outros como José, Jesus e Maria Madalena, optando pela fidelidade às leis de seu tempo, e, logo, pela passividade.

\section{2) JESUS}

Jesus, considerando apenas sua forma de lidar com as mulheres, não foi uma personagem muito alterada por Saramago. Assim como no texto bíblico original, Jesus inspira uma aceitação geral, que inclui muitos dos grupos marginalizados de sua época - entre esses, as mulheres. Diversas situações exemplificam este aspecto da personagem, desde simplesmente dirigir a palavra a uma mulher (o que já é classificado tanto na Bíblia quanto na releitura de Saramago como algo passível de punição social e, por vezes, jurídica) à sua união com Maria de Magdala em "concubinato", nos termos do autor. Pode-se exemplificar sua relação geral para com o sexo feminino com um conhecido episódio bíblico resgatado pelo autor com poucas alterações:

[...] o segundo teve mais que se lhe diga porque representou um desafio frontal de Jesus à lei escrita e observada, acaso justificável, tendo em conta os comportamentos humanos normais, por viver Jesus com Maria de Magdala sem com ela estar casado, prostituta que havia sido, ainda por cima, por isso não se devia estranhar que estando uma mulher adúltera a ser apedrejada, conforme a lei de Moisés, e disso devendo morrer, aparecesse Jesus a interpor-se e a perguntar, Alto lá, quem de vós estiver sem pecado, seja o primeiro a lançar-lhe uma pedra [...]. Jesus disse à adúltera, Vai e doravante não tornes a pecar, mas no íntimo ia cheio de dúvidas (SARAMAGO, 2011, pp. 293-294). 
É interessante notar, entretanto, que uma destas alterações é de grande relevância à construção da personagem de Jesus. No ESJC, o narrador faz alusão a um motivo para a ação de Jesus inexistente nos Evangelhos: ele defende a mulher adúltera por entendêla, já que ele mesmo vive com uma ex-prostituta sem estar casado. Pode-se perceber que, se na Bíblia as ações e pensamentos de Jesus para com as mulheres baseava-se num sentimento de compaixão sem restrições (tal sentimento era apresentado como igual a todos, sem diferir sexos), na releitura tais se justificam por um certo egocentrismo, que apesar de produzir os mesmos resultados diminui o caráter divino (do "amor universal") e aproxima a personagem de emoções mesquinhas, mais associadas a um caráter humano. Outro detalhe importante é que Jesus perdoa, mas tal perdão é posterior a uma condenação. Jesus, apesar de ir contra a punição da mulher adúltera, condena o adultério, gerando uma leve sensação antitética representada pelas "dúvidas" "no [seu] íntimo". Mesmo assim, a rebeldia de Jesus às normas patriarcais no episódio, assim como a sua relação com Maria de Magdala (a ser melhor abordada no próximo tópico), demonstra a singularidade da visão de Jesus acerca das mulheres.

É também notável que, no ESJC, a única personagem feminina que realmente vai de encontro a Jesus, sendo por isso excluída por anos de sua vida, é a própria Maria. Isso pode ser facilmente justificado pela própria construção da personagem da mãe de Jesus (convencional, como caracterizada anteriormente), por sua adoção incondicional às regras sociais e religiosas, o que acaba por afastar dela o próprio filho. Não há, entretanto, rompimento total de relações entre os dois: Jesus, nas poucas vezes que a encontra após deixar a casa em que cresceu, atende seus pedidos (como no episódio do casamento em Caná) e leva em consideração seus conselhos, mesmo que nem sempre os aceite.

\section{3) MARIA DE MAGDALA}

Maria de Magdala, na tradução brasileira da Bíblia conhecida como Maria Madalena, é talvez a personagem mais relevante a esta análise. Seu papel no ESJC é semelhante ao de Lilith em Caim, considerando a força de sua presença na narrativa. É importante notar que sua representação nos Testamentos é ínfima - como acontece com muitas das mulheres presentes na Bíblia, sua participação parece constantemente omitida e diminuída (PAGOLA, 2010, pp. 255-256). Saramago altera drasticamente esse aspecto em sua releitura: a personagem de Maria de Magdala é ampliada e aprofundada, sendo construída narrativamente como uma das protagonistas do romance. Isso já pode ser percebido desde sua primeira aparição no texto:

[...] Jesus chamou, Ó de dentro, disse, e, acto contínuo, uma mulher apareceu à porta, como se justamente estivesse à espera de que a chamassem, embora, por um leve ar de surpresa que começou por aparecer-lhe na cara, pudéssemos ser levados a pensar que estaria antes habituada a que lhe entrassem pela casa dentro, sem bater, o que, se bem considerarmos as coisas, teria menos razão de ser que em outro qualquer caso, pois esta mulher é uma prostituta e o respeito que deve à sua profissão manda-lhe que feche a porta de casa quando recebe um cliente. Jesus, que estava sentado no chão, comprimindo a desatada ferida, olhou de relance a mulher que se lhe acercava, Ajuda- 
me, disse, e, tendo segurado a mão que ela lhe estendia, conseguiu pôr-se de pé e dar uns passos, coxeando. Não estás em estado de andar, disse ela, entra, que eu trato-te dessa ferida (SARAMAGO, 2011, p. 230).

Já nesse curto trecho, uma alteração muito significativa à construção de Maria de Magdala é feita: diferentemente do texto bíblico, que conta sobre o relacionamento de Jesus e Maria de Magdala pouco além de ter ele "expulsado sete demônios" (Lucas, 8, 2) dela (logo, que ela foi ajudada por Jesus), tem-se aqui uma inversão direta de posições desde o princípio. Jesus pede socorro a Maria de Magdala, que não hesita em ajudá-lo nem por um segundo. Essa tampouco é a única vez que ela o ajuda exemplos de tal se acumulam ao longo da narrativa. Outro destes, também marcante ao texto, é narrado pouco depois:

[...] depois Jesus fez voltar ao alforge o mísero conteúdo, quando de súbito deu por que uma ponta da túnica fazia um nó volumoso e percebeu que o nó era pesado e, sendo-o, ao pensá-lo subiu-lhe o sangue à cara, só podia conter dinheiro, esse mesmo que negara possuir, e que o dinheiro fora ali posto por Maria de Magdala, ganho portanto, não com o suor do rosto, como manda a dignidade, mas com gemidos falsos e suores suspeitos (SARAMAGO, 2011, pp. 244-245).

O dinheiro escondido por Maria de Magdala no alforge de Jesus é altamente representativo. Com ele pode-se perceber não apenas o ímpeto de auxílio da personagem, mas também seus aspectos econômicos: Maria de Magdala, prostituta, consegue em meio a uma sociedade que a constrange com normas misóginas exercer uma função que, apesar de suas possíveis condenações morais, permite-lhe ser independente. Lembrando novamente Neto, "[a]s mulheres saramaguianas, sobretudo as protagonistas, não pertencem a ninguém" (NETO, 2012, p. 98). Esse aspecto, por si só, já a coloca em uma posição de poder raramente evidenciada em mulheres da época. Mais que isso: essa independência é uma condição primária para todo o seu relacionamento com Jesus, visto que sem ela não só a personagem não teria uma forma de sustento, mas tampouco poderia sequer dirigir a palavra a um homem, caso não houvesse, ela mesma, rejeitado o padrão feminino que lhe era imposto pela comunidade. E, mesmo com todas essas atitudes de "rebeldia social", não demonstra vergonha por exercer tal profissão - declara-a desde o início a Jesus, assim como à própria Maria.

Focando na questão do auxílio de Maria de Magdala a Jesus, tal não se restringe à área econômica ou a um simples cuidado médico, como mostrado nas passagens anteriores. Maria de Magdala, em diversas ocasiões, coloca-se como uma guia de Jesus em situações das mais variadas: seja em impasses morais, como quando diz para Jesus não ressuscitar Lázaro (irmão da própria Maria de Magdala) declarando que "ninguém na vida teve tantos pecados que mereça morrer duas vezes" (SARAMAGO, 2011, p. 360), demonstrando uma visão mais clara da situação e uma forte compreensão moral; seja em quesitos sexuais, como no trecho a seguir, no qual Jesus tem a sua primeira relação com Maria de Magdala:

Maria de Magdala conduziu Jesus até junto do forno [...], por suas mãos o despiu e lavou, às vezes tocando-lhe o corpo, aqui e aqui, e aqui, com as pontas dos dedos, 
beijando-o de leve no peito e nas ancas, de um lado e do outro. Estes roces delicados faziam estremecer Jesus, as unhas da mulher arrepiavam-no quando lhe percorriam a pele, Não tenhas medo, disse Maria de Magdala, [...], Deita-te, eu volto já, [...] e Maria de Magdala apareceu, nua. [...] Maria se deitou ao lado dele, e, tomando-lhe as mãos, puxando-as para si, as fez passar, lentamente, por todo o seu corpo [...] e dizia, Aprende o meu corpo, aprende o meu corpo (SARAMAGO, 2011, pp. 233-234).

Desta forma, no relacionamento de Maria de Magdala e Jesus, a primeira parece ocupar uma posição superior sexual, moral e intelectualmente, o que acaba por dar-lhe também um poder de decidir por ambos. Socialmente, Jesus não perde o seu papel central, mas este detalhe só subsiste através da mentalidade comum da época. Ainda assim, tal "domínio" de Maria de Magdala sobre seu companheiro é claro até mesmo para eles próprios:

E como posso ser o teu amado se não me conheces, se sou apenas alguém que te veio pedir ajuda e de quem tiveste pena, pena das minhas dores e da minha ignorância, Por isso te amo, porque te ajudei e te ensinei, mas tu a mim é que não poderás amar-me, pois não me ensinaste nem ajudaste (SARAMAGO, 2011, p. 236).

Este trecho leva a outro aspecto importante da relação de Maria de Magdala com Jesus: a posição maternal assumida por ela sobre ele. Maria de Magdala, ao encontrar Jesus, vê nele uma espécie de pupilo, alguém que aceitaria seus "sete demônios" (lembrando o original bíblico) e a quem ela poderia ajudar a desenvolver-se moral e intelectualmente. Tal aspecto é inclusive aludido na obra, quando ela pensa que "quer a Jesus como mulher, mas desejaria querê-lo também como mãe" (SARAMAGO, 2011, p. 276). Assim, se "guia" e "professora" não parecem boas palavras para classificar Maria de Magdala em relação a Jesus, Saramago mostra que as melhores opções talvez sejam "mulher" e "mãe", levando em conta toda a importância de ambos os papéis na vida de um homem, principalmente de um perdido em meio a tantas questões humanas e divinas.

\section{4) CONSIDERAÇÕES FINAIS}

Fica claro nas releituras analisadas a grande ampliação dos papeis das personagens bíblicas femininas. Se uma tentativa semelhante já fosse esperada, conhecendo-se as características do autor evidenciadas por outras de suas obras, ainda é surpreendente a força demonstrada por personagens já tão culturalmente arraigadas de ideologias e conceitos misóginos. Saramago consegue trazer a histórias que fazem parte da consciência coletiva há milênios um olhar próprio e questões contemporâneas, botando em cheque muitos dos aspectos passíveis de críticas presentes nos Evangelhos. E o resultado, apesar de toda a polêmica que o cerca, é extraordinário.

\section{Referências}


BEAUVOIR, S. de. O segundo sexo. $4^{\text {a }}$ ed. São Paulo: Difusão Europeia do Livro, 1970.

BÍBLIA, Português. Bíblia Sagrada. Tradução dos Monges Beneditinos de Maredsous. São Paulo: Editora Ave-Maria, 2008. Edição Claretiana.

BONNICI, T.; ZOLIN, L. O. (Orgs.) Teoria Literária: abordagens históricas e tendências contemporâneas. Maringá: EDUEM, 2003.

COSTA, C. L. A ética em O segundo Jesus Cristo, de José Saramago. In: FERRAZ, S., et al. (Orgs.). Deuses em poéticas: estudos de literatura e teologia. Belém: UEPA; Campina Grande: EDUEPB, 2008, pp. 181-192.

CULLER, J. Teoria literária: uma introdução. São Paulo: Beca Produções Ltda, 1999.

NETO, P. F. de O. Retratos para a construção do feminino na prosa de José Saramago. $1^{\text {a }}$ ed. Curitiba: Editora Appris, 2012.

NIETZSCHE, F. Genealogia da moral: uma polêmica. São Paulo: Companhia das Letras, 2009.

NIETZSCHE, F. Para além do bem e do mal. 1ª ed. São Paulo: Martin Claret, 2002.

PAGOLA, Jose Antonio. Jesus: aproximação histórica. Petrópolis: Vozes, 2010, pp. 255-285.

SARAmago, J; AGUILERA, F. G. (Org.) As palavras de Saramago. São Paulo: Companhia das Letras, 2010.

SARAMAGO, J. Caim. 5a ed. São Paulo: Companhia das Letras, 2009.

SARAMAGO, J. O evangelho segundo Jesus Cristo. $13^{\text {a }}$ ed. São Paulo: Companhia das Letras, 2011.

SCHACH, V. A. A nova realidade feminina com o fim do androcentrismo a partir de Jesus. Revista Batista Pioneira, Rio Grande do Sul, v. 1, n. 1, jun. 2012. Disponível em: <http://revista.batistapioneira.edu.br/>. Acesso em: 26 jan. 2015.

SICUTERI, R. Lilith: a lua negra. $3^{\text {a }}$ ed. São Paulo: Paz e Terra, 1987.

SILVA, L. C. F.; SILVA, M. C. A personagem feminina em Saramago. Disponível em: <http://cac-php.unioeste.br/eventos/iisnel/CD_IISnell/pages/simposios/simposio\%2006/ A\%20PERSONAGEM\%20FEMININA\%20EM\%20SARAMAGO.pdf>. Acesso em: 29 jan. 2015. 